\title{
THE INVENTION AND DEFINITION OF ALLOY 625
}

\author{
H. L. Eiselstein and D. J. Tillack
}

Inco Alloys International, Inc.

\author{
P. O. Box 1958
}

Huntington, WV 25720

\begin{abstract}
The filing of a patent application for alloy 625 on January 24, 1962, marked the culmination of nearly a decade of research on the basic Ni-Cr-Mo-Nb alloy system. This paper describes the research and development effort that resulted in the invention of alloy 625 , how some of the problems that were encountered along the way were solved and how numerous variants of the alloy were developed. One of the remarkable aspects of the research effort is that it also resulted in the invention of alloy 718 .
\end{abstract}




\section{Introduction}

The development of INCONEL ${ }^{\circledR}$ alloy 625 (UNS N06625) was started in the 1950 s to meet the then-perceived demand for a high-strength main steam-line piping material. After several years of discovering how various elements affected the properties and fabricability of the alloy system, a patent application was submitted on January 24, 1962. Patent $\# 3,160,500$ was issued to H. L. Eiselstein and J. Gadbut on December 8, 1964. The present composition for alloy 625 is listed in Table $\mathrm{I}$.

Table I. INCONEL alloy 625 Typical Composition (\%)

\begin{tabular}{|c|c|c|c|c|c|c|c|c|c|c|}
\hline $\mathrm{Ni}$ & $\mathrm{Cr}$ & $\mathrm{Mo}$ & $\mathrm{Nb}$ & $\mathrm{Fe}$ & $\mathrm{C}$ & $\mathrm{Si}$ & $\mathrm{Al}$ & $\mathrm{Ti}$ & $\mathrm{Mn}$ & $\mathrm{S}$ \\
\hline \hline $\mathrm{61}$ & 21.5 & 9 & $\mathbf{3 . 6}$ & 2 & .05 & .20 & .20 & .20 & .20 & .001 \\
\hline
\end{tabular}

The story of the invention and definition of alloy 625 reflects the triumphs, frustrations and surprises that often accompany the stimulating world of the metallurgical R\&D laboratory.

\section{Genesis - The Early Work}

In the 1950 s there seemed to be an opportunity developing for a main steam-line material for super critical steam power plants. One such power facility, the Eddystone plant near Philadelphia, was being built using 316 stainless steel. This plant used $649^{\circ} \mathrm{C}\left(1200^{\circ} \mathrm{F}\right)$ steam at $13.8 \mathrm{MPa}$ (2000 psi). The product goals for our development were weldability, high creep resistance, fabricable into tubing, non-agehardening, and otherwise have attractive ASME Boiler Code design properties. This was to be, what we called, a matrix stiffened alloy, with a nickel-based composition. Along the way to a product our goals were modified considerably, except for weldability.

Work had already been done in the 1950s on the strengthening effects of various amounts of the common major alloying elements, i.e., chromium, molybdenum, niobium** aluminum, and titanium in an INCONEL alloy 600 base. (INCONEL alloy $X-750$, which is strengthened by titanium and aluminum, had been around for several years.) The strengthening effects of these elements one at a time were not impressive. So it was decided to use molybdenum and niobium in combination with varying amounts of nickel. Because an alloy goal was metallurgical stability, tensile samples of each alloy were given a simple aging treatment, such as $704^{\circ} \mathrm{C}\left(1300^{\circ} \mathrm{F}\right)$ for 16 hours, and tested at room temperature. It was hoped that these tests would indicate any tendencies for age hardening or embrittlement, which they did in a spectacular way. The net result is shown in Figure 1. ${ }^{(1)}$ These results delayed the development of alloy 625 and started one which resulted in INCONEL alloy 718. A patent application for alloy 718 was filed on November. 13, 1958, and the patent was issued on July $24,1962(\# 3,046,108)$.

()INCONEL is a trademark of the Inco family of companies.

**Note: In all cases throughout this paper, the percent niobium is intended to be interpreted as niobium + tantalum, with the tantalum comprising less than $10 \%$ of the total niobium + tantalum content. 


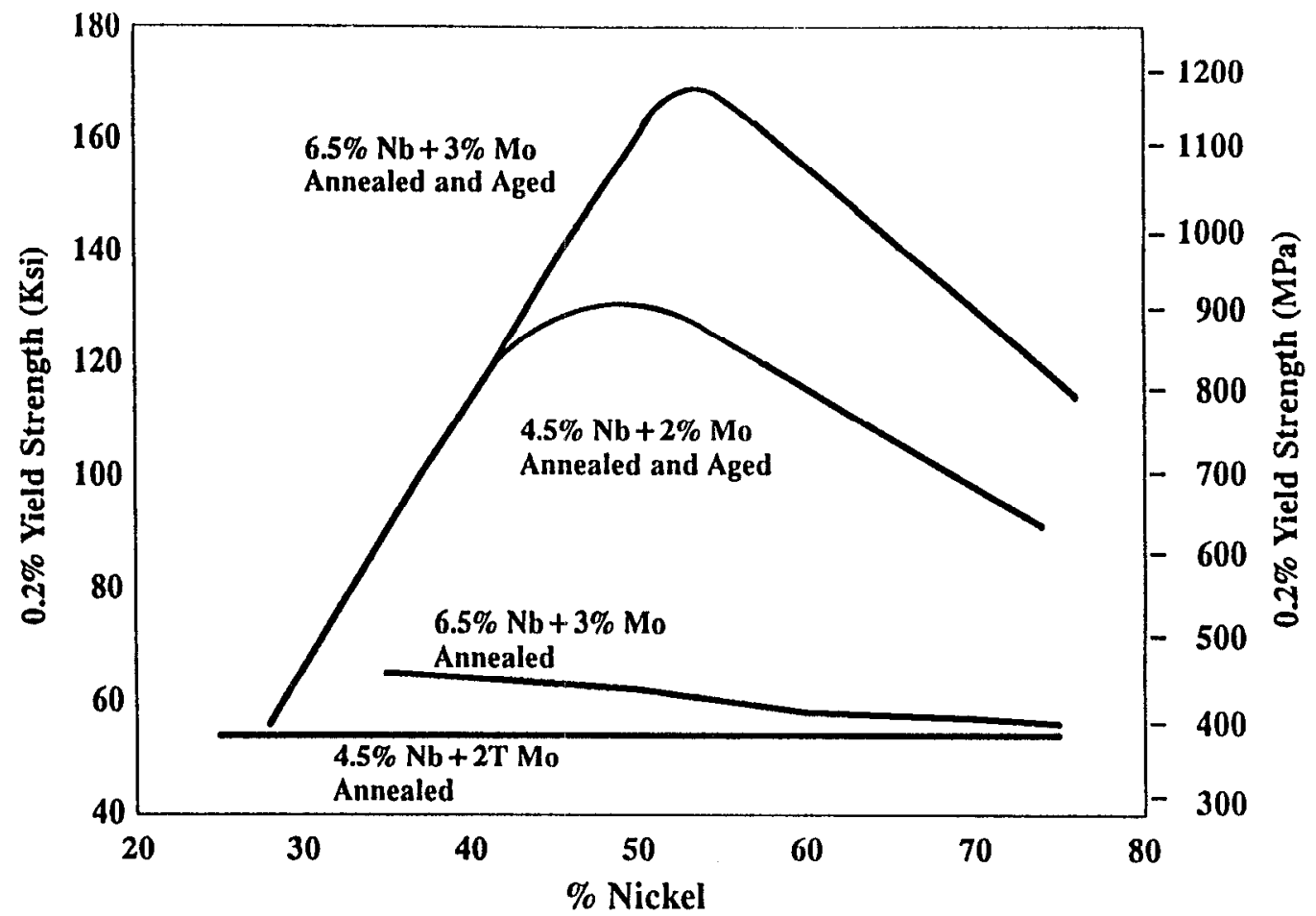

Figure 1. Effect of Ni and Nb Content on Room Temperature Yield Strength of Annealed and Aged $\mathrm{Ni}, \mathrm{Cr}, \mathrm{Nb}, \mathrm{Mo}, \mathrm{Al}, \mathrm{Ti}$, Bal. Fe Alloys. Annealed and Aged =

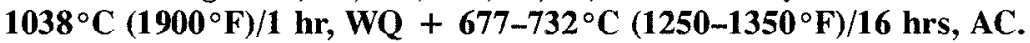

Annealed $=1038^{\circ} \mathrm{C}\left(1900^{\circ} \mathrm{F}\right) / 1 \mathrm{hr}, \mathrm{WQ}+$ no aging.

After the hiatus caused by the alloy 718 development, the market for a nickel-based alloy for super critical steam had vanished. The alloy composition of the matrix-stiffened alloy, code named MS-2, when development efforts resumed was approximately $60 \mathrm{Ni}, 15 \mathrm{Cr}$, $3 \mathrm{Nb}, 2 \mathrm{Mo}, 0.5 \mathrm{Al}, 0.5 \mathrm{Ti}$ and balance $\mathrm{Fe}$. In the annealed state this alloy was a little harder than alloy 600 and could have been easily fabricated into all standard mill products. Then it was suggested that the alloy could more readily compete with already established alloys in the marketplace if it had higher room temperature tensile properties. Fortunately for the alloy 625 development, the elements chromium and molybdenum that were used to increase room temperature strength also greatly increased the corrosion resistance. This change in composition altered the course of development of this alloy and increased its marketing opportunities. Because of the higher strength there were problems in producing some products, but weldability was not impaired. The chromium and molybdenum contents were raised to their current levels of $22 \%$ and $9 \%$ respectively.

\section{Effects of Elements on Strength}

By using factorial experiments the appropriate levels of niobium, molybdenum, aluminum, titanium and chromium were determined. The niobium solubility in the alloy appeared to be about $2.5 \%$ and increased with decreasing $\mathrm{Mo}+\mathrm{Cr}$ content. The aluminum solubility was determined to be about $0.5 \%$. 


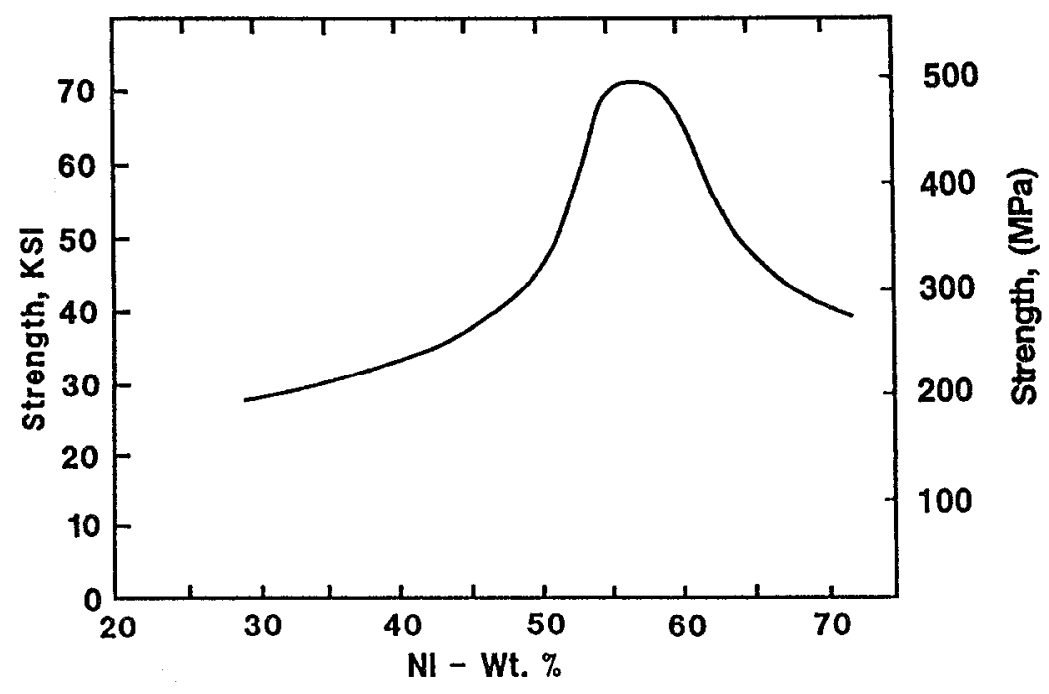

Figure 2. Effect of Nickel on $1000 \mathrm{hr} 649^{\circ} \mathrm{C}\left(1200^{\circ} \mathrm{F}\right)$ Rupture Strength Annealed $1038^{\circ} \mathrm{C}\left(1900^{\circ} \mathrm{F}\right)$ for $1 \mathrm{Hr}$.

Note: Balance of Composition: 13-21 Cr, $4.25 \mathrm{Nb}, 2-3 \mathrm{Mo}, .1-.25 \mathrm{Al}$, .1-.25 Ti, .2 Si, .2 Mn, .02-.04 C, Bal Fe.

The effect of nickel on the $1200^{\circ} \mathrm{F}$ stress-rupture strength of annealed 625, as shown in Figure 2, shows a peak around $57 \%$. Figure 3 demonstrates only a slight matrix stiffening effect of niobium (the annealed curve) and a significant increase in annealed + aged yield strength beyond about $3 \%$ niobium. Alloy 718 had lower solubility for niobium, and consequently higher annealed + aged strength, due to lower nickel and higher aluminum and titanium content. (The rate of increase of yield strength with niobium in the annealed + aged condition for alloy 625 is probably a result of the difference in aging time for the two alloys.)

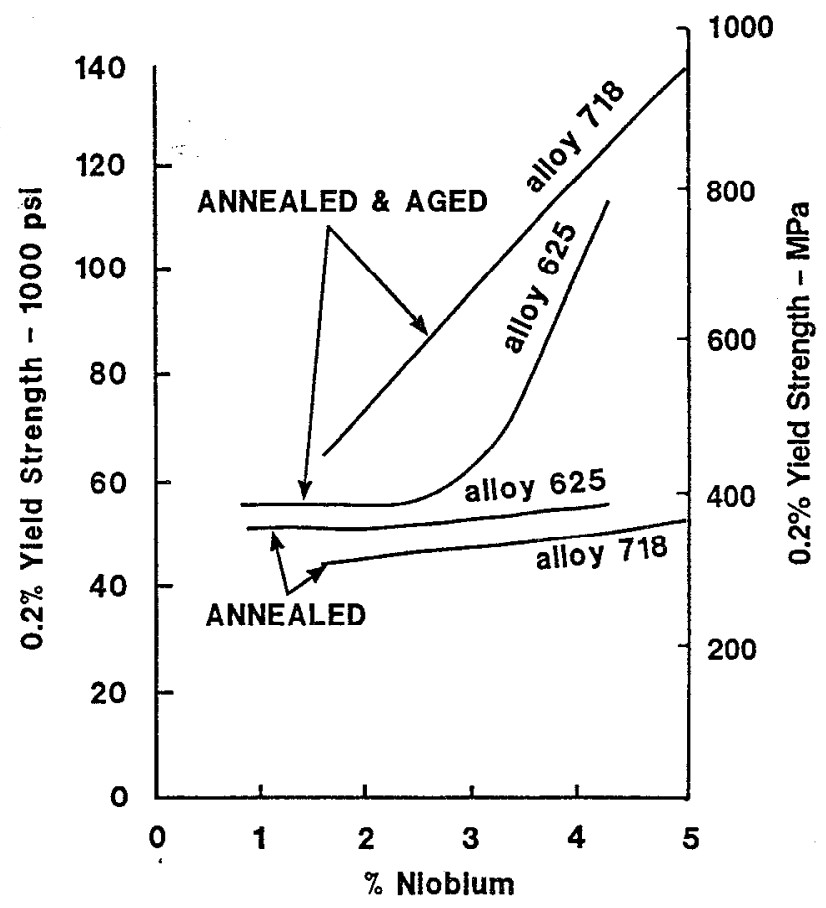

Figure 3. Effect of $\% \mathrm{Nb}$ on $0.2 \%$ Y.S. of alloy 625 and alloy 718 .

Little change in properties was noticed with niobium additions up to $2 \%$. Molybdenum increased the strength of the matrix and may alone or through some interaction with niobium increase the age-hardening response and decrease the impact strength after exposure. Increasing chromium content from $16 \%$ to $22 \%$ caused an increase in the strength of the 
matrix but did not appear to have any effect on the age-hardening response at these levels of chromium. Molybdenum, chromium and especially niobium impart creep strength to the alloy. These effects are shown in Figures 4 and 5.

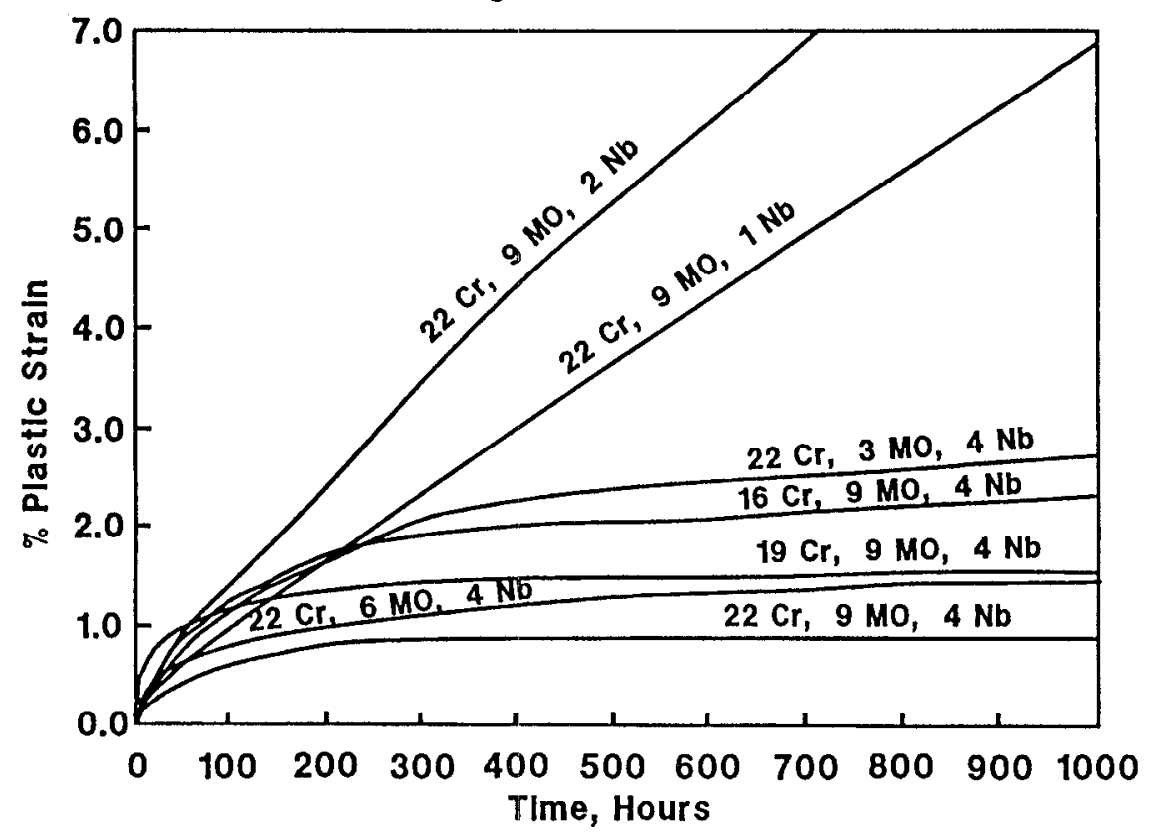

Figure 4. Creep Tests at $816^{\circ} \mathrm{C} / 52 \mathrm{MPa}\left(1500^{\circ} \mathrm{F} / 7500 \mathrm{psi}\right)$

Aluminum and titanium were intentionally kept low to minimize the age-hardenability of the alloy. Creep tests performed at $649^{\circ} \mathrm{C}\left(1200^{\circ} \mathrm{F}\right)$ showed a considerable benefit, however, in retaining a level of around $0.2 \%$, versus $0.0 \%$, for each of these elements. An added advantage to a low level of $\mathrm{Al}+\mathrm{Ti}$ was improved weldability and brazeability. Nickel plating, which was almost a necessity when brazing alloys with higher levels of $\mathrm{Al}+\mathrm{Ti}$, was unnecessary.

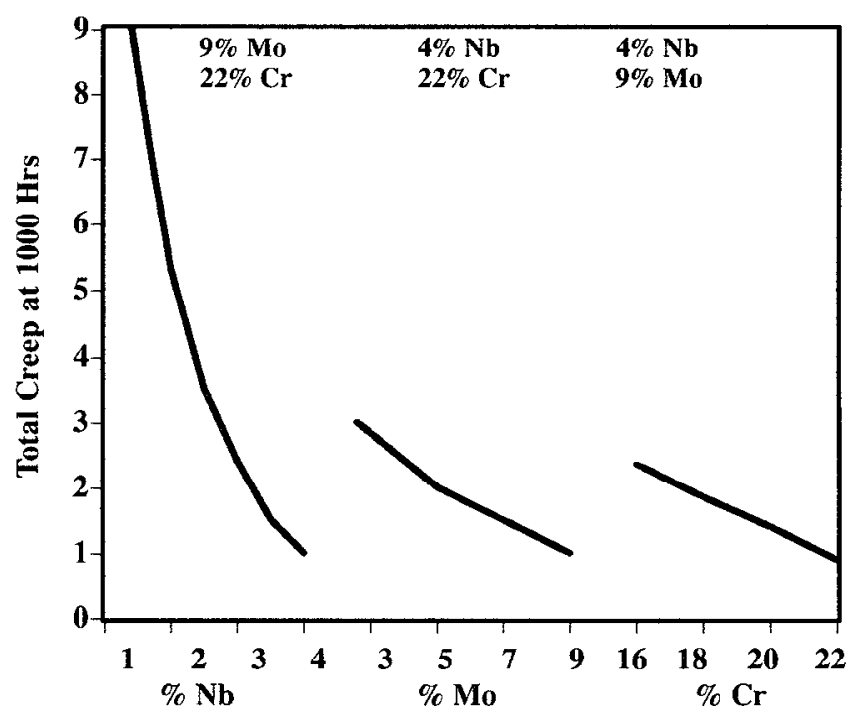

Figure 5. Effect of $\mathrm{Nb}, \mathrm{Mo}$ and $\mathrm{Cr}$ on the Creep Strength of INCONEL alloy 625 Forged Squares $+1149^{\circ} \mathrm{C}\left(2100^{\circ} \mathrm{F}\right) / 1$ hr at $816^{\circ} \mathrm{C} / 66 \mathrm{MPa}\left(1500^{\circ} \mathrm{F} / 9500 \mathrm{psi}\right)$

\section{Stability}

Early on, Jim Barker of the General Electric Aircraft Engines plant at Evendale, Ohio, called our attention to age hardening effects in alloy 625 caused by long-time exposure to intermediate temperatures. These exposure times were much longer than the 16 hours 
used in the screening tests and they showed that that composition was quite age hardenable, but only for uneconomically long aging times of about 200 hours at $649^{\circ} \mathrm{C}$ $\left(1200^{\circ} \mathrm{F}\right)$. The composition was modified by reducing the amount of aluminum and titanium in the alloy to the present amount.

In the mid to late 1960s, Knolls Atomic Power Laboratory (KAPL) and the Naval Reactor Task Force Group expressed interest in large-cross-section alloy 625 with higher [552 $\mathrm{MPa}(80 \mathrm{ksi})$ ] yield strength. KAPL proposed increasing the niobium content to $4 \%$ or over but Inco preferred to develop the desired properties by control of thermal-mechanical processing and heat-treatment. A higher-niobium version of alloy 625 would cause the usual commercial problems that a new alloy would create, such as duplicate stocking and segmented market demand, in addition to manufacturing problems such as increased segregation problems during melting, poorer malleability and resulting lower product yields.

Prior laboratory studies had shown that large sections would require a final thermal processing step to insure meeting the desired $552 \mathrm{MPa}(80 \mathrm{ksi})$ minimum yield strength. Thermal strengthening was known to be significant but sluggish, occurring in a narrow temperature range around $649^{\circ} \mathrm{C}\left(1200^{\circ} \mathrm{F}\right)$ with most response within 48 hours. Warm work aided the strengthening process but inhomogeneous strain could cause considerable variation in properties from center to edge in large cross-sections. An annealing temperature of $871-927^{\circ} \mathrm{C}\left(1600-1700^{\circ} \mathrm{F}\right)$ maximum was required to ensure achieving the $414 \mathrm{MPa}(60 \mathrm{ksi})$ minimum yield strength in large [20.3-25.4cm (8-10") diameter] cross-sections, while a heat-treatment of $649^{\circ} \mathrm{C}\left(1200^{\circ} \mathrm{F}\right)$ for $24-48$ hours was needed to achieve the $552 \mathrm{MPa}(80 \mathrm{ksi})$ level. Table ll gives data for three $25.4 \mathrm{~cm}$ (10") hot-pressed octagons from different heats of material showing the as-pressed, annealed and annealed plus $649^{\circ} \mathrm{C}\left(1200^{\circ} \mathrm{F}\right) / 48$ hours age properties.

Table II. Effects of Forging and Aging on INCONEL alloy 625 on Room Temperature Properties

\begin{tabular}{|c|c|c|c|c|}
\hline Heat Treat Code & Property & $\begin{array}{c}\text { Heat49A3 } \\
\mathbf{( 9 . 0 0 ~ M o , 3 . 5 1 ~ N b ) ~}\end{array}$ & $\begin{array}{c}\text { Heat 50A0 } \\
(\mathbf{9 . 1 8} \mathbf{M o , 3 . 4 6 N b})\end{array}$ & $\begin{array}{c}\text { Heat 65A6 } \\
(\mathbf{9 . 0 3} \mathbf{M o , 3 . 5 2 N b})\end{array}$ \\
\hline \hline A & $2 \%$ YS-MPa(Ksi) & $672(98)$ & $524(76)$ & $434(63)$ \\
& UTS-MPa(Ksi) & $979(142)$ & $869(126)$ & $854(124)$ \\
& Elongation(\%) & 41 & 50 & 56 \\
Hardness & $26 \mathrm{Rc}$ & $97 \mathrm{Rb}$ & $94 \mathrm{Rb}$ \\
\hline $\mathrm{B}$ & $2 \%$ YS-MPa(Ksi) & $400(58)$ & $510(74)$ & $434(63)$ \\
Forged $+927^{\circ} \mathrm{C}$ & UTS-MPa(Ksi) & $862(125)$ & $848(123)$ & $848(123)$ \\
$\left(1700^{\circ} \mathrm{F}\right) / 1 \mathrm{Hr}$ & Elongation(\%) & 52 & 49 & 54 \\
Air Cool & Hardness & $93 \mathrm{Rb}$ & $96 \mathrm{Rb}$ & $93 \mathrm{Rb}$ \\
\hline $\mathrm{C}$ & $2 \%$ YS-MPa(Ksi) & $889(129)$ & $724(105)$ & $710(103)$ \\
Forged $+649^{\circ} \mathrm{C}$ & UTS-MPa(Ksi) & $1172(170)$ & $1020(148)$ & $1055(153)$ \\
$\left(1200^{\circ} \mathrm{F}\right) / 48 \mathrm{Hr}$ & Elongation(\%) & 30 & 37 & 43 \\
Air Cool & Hardness & $34 \mathrm{Rc}$ & $28 \mathrm{Rc}$ & $29 \mathrm{Rc}$ \\
\hline
\end{tabular}

Product: $25.4 \mathrm{~cm}$ (10") Pressed Octagon

All Tests: Room Temperature, Longitudinal, Mid-Radius

All Heats: Double Vacuum Melted (VIM+VAR)

The aging response of alloy 625 is sensitive to annealing temperature, with higher temperature anneals resulting in less response to direct aging heat treatments in smaller 
sized specimens. In larger sized specimens [e.g. $25.4 \mathrm{~cm}\left(10^{\prime \prime}\right)$ thick] the slower cooling rate from the annealing temperature permits the material to spend a sufficient amount of time in the nucleation temperature range of $732-843^{\circ} \mathrm{C}\left(1350-1550^{\circ} \mathrm{F}\right)$. This dwell time in this temperature range triggers the precipitation reaction and allows faster growth of subcritical gamma double prime $\left(\gamma^{\prime \prime}\right)$ nuclei, thus permitting a normal, though slow, precipitation of the Body Centered Tetragonal (BCT) $\gamma^{\prime \prime}$ particles during the lengthy aging treatment at $649^{\circ} \mathrm{C}\left(1200^{\circ} \mathrm{F}\right)$. A time of between 2 and 4 minutes in the critical $760-788^{\circ} \mathrm{C}$ $\left(1400-1450^{\circ} \mathrm{F}\right)$ temperature range is apparently necessary to cause more rapid aging at $649^{\circ} \mathrm{C}\left(1200^{\circ} \mathrm{F}\right)$.

If smaller diameter samples are given a high-temperature anneal, such as $1149^{\circ} \mathrm{C}$ $\left(2100^{\circ} \mathrm{F}\right)$, an extremely long time is needed to produce an aging reaction at $649^{\circ} \mathrm{C}$ $\left(1200^{\circ} \mathrm{F}\right)$ unless an intermediate nucleation heat treatment of $760^{\circ} \mathrm{C}\left(1400^{\circ} \mathrm{F}\right) / 1$ hour is performed prior to the $649^{\circ} \mathrm{C}\left(1200^{\circ} \mathrm{F}\right)$ aging treatment. A comparison of aging times needed to achieve appreciable hardening is shown in Figure 6 . After a $1149^{\circ} \mathrm{C}\left(2100^{\circ} \mathrm{F}\right) / 1$ hour anneal no increase in hardness was observed after 96 hours at $649^{\circ} \mathrm{C}\left(1200^{\circ} \mathrm{F}\right)$ in a sample that did not have the $760^{\circ} \mathrm{C}\left(1400^{\circ} \mathrm{F}\right) / 1$ hour nucleation treatment, whereas the sample that had received the nucleation treatment had an increase in hardness of 11 Rockwell A points after the $649^{\circ} \mathrm{C}\left(1200^{\circ} \mathrm{F}\right) / 96$ hour age.

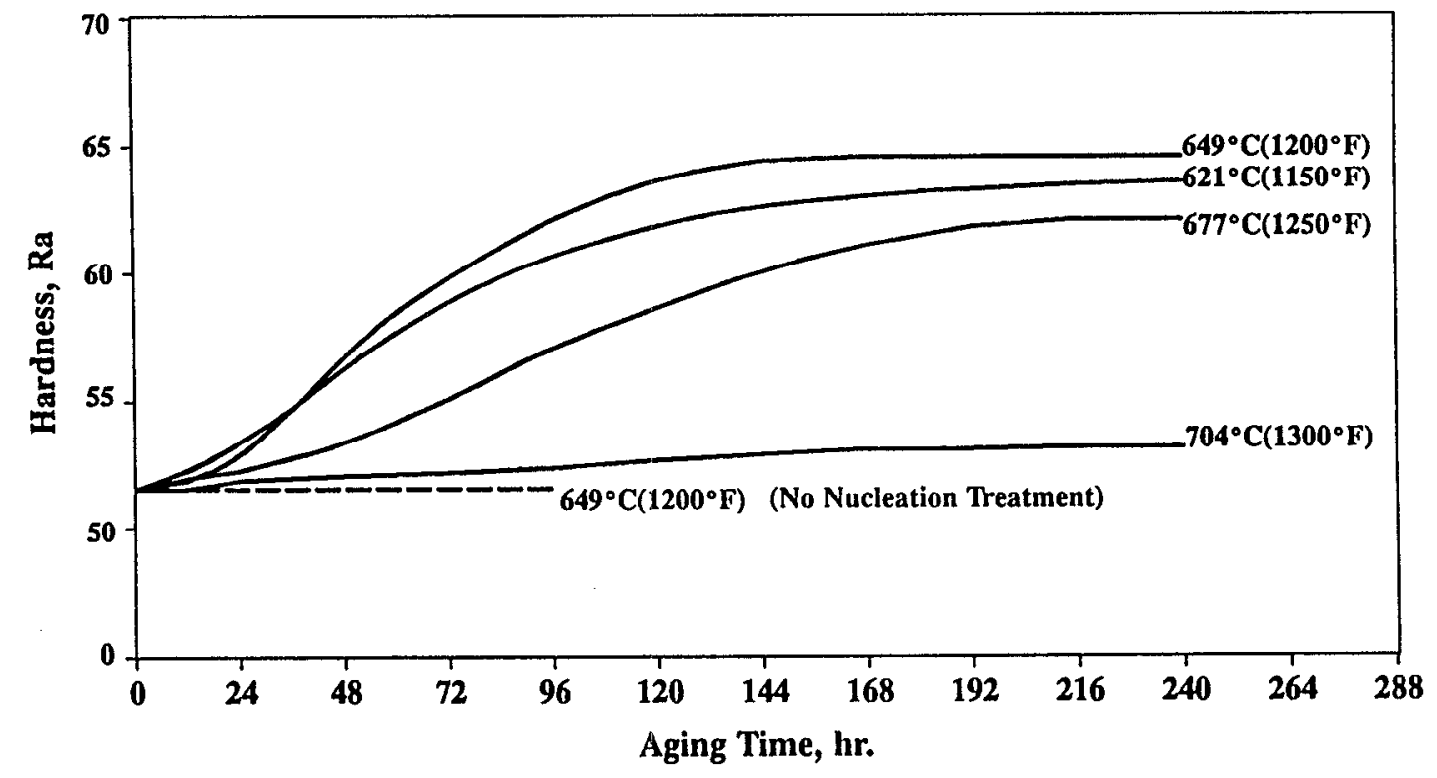

Figure 6. Aging Response of INCONEL alloy 625 annealed at $1149^{\circ} \mathrm{C}\left(2100^{\circ} \mathrm{F}\right) / 1 \mathrm{hr}$ and Nucleation-Treated at $760^{\circ} \mathrm{C}\left(1400^{\circ} \mathrm{F}\right) / 1 \mathrm{hr}$.

Alloy 625 does not precipitate the familiar Face Centered Cubic (FCC) gamma prime $\left(\gamma^{\prime}\right)$ found in most Al-Ti hardened alloys, but rather a metastable BCT $\left(\gamma^{\prime \prime}\right)$, which has a stacking sequence abcdef, and a stable orthorhombic $\mathrm{Ni}_{3} \mathrm{Nb}$ phase, with an abab stacking sequence. The BCT $\gamma^{\prime \prime}$ phase confers the most strength to the alloy, and it is the phase of most use in age hardening. The orthorhombic $\mathrm{Ni}_{3} \mathrm{Nb}$ phase is not coherent with the matrix and contributes to hardening only as a dispersant. 
The dead-soft base strength of alloy 625 is about $345 \mathrm{MPa}(50 \mathrm{ksi})$ yield strength. While a minimum room-temperature yield strength of $414 \mathrm{MPa}(60 \mathrm{ksi})$ is achievable in most cross-sections, higher minimum values are only achievable by age hardening for prolonged periods of time, such as $24-48 \mathrm{hrs}$ at $649^{\circ} \mathrm{C}\left(1200^{\circ} \mathrm{F}\right)$, or by cold working. Figure 7 shows a plot of room-temperature yield strength after exposure to intermediate temperatures for various times up to 1000 hours.

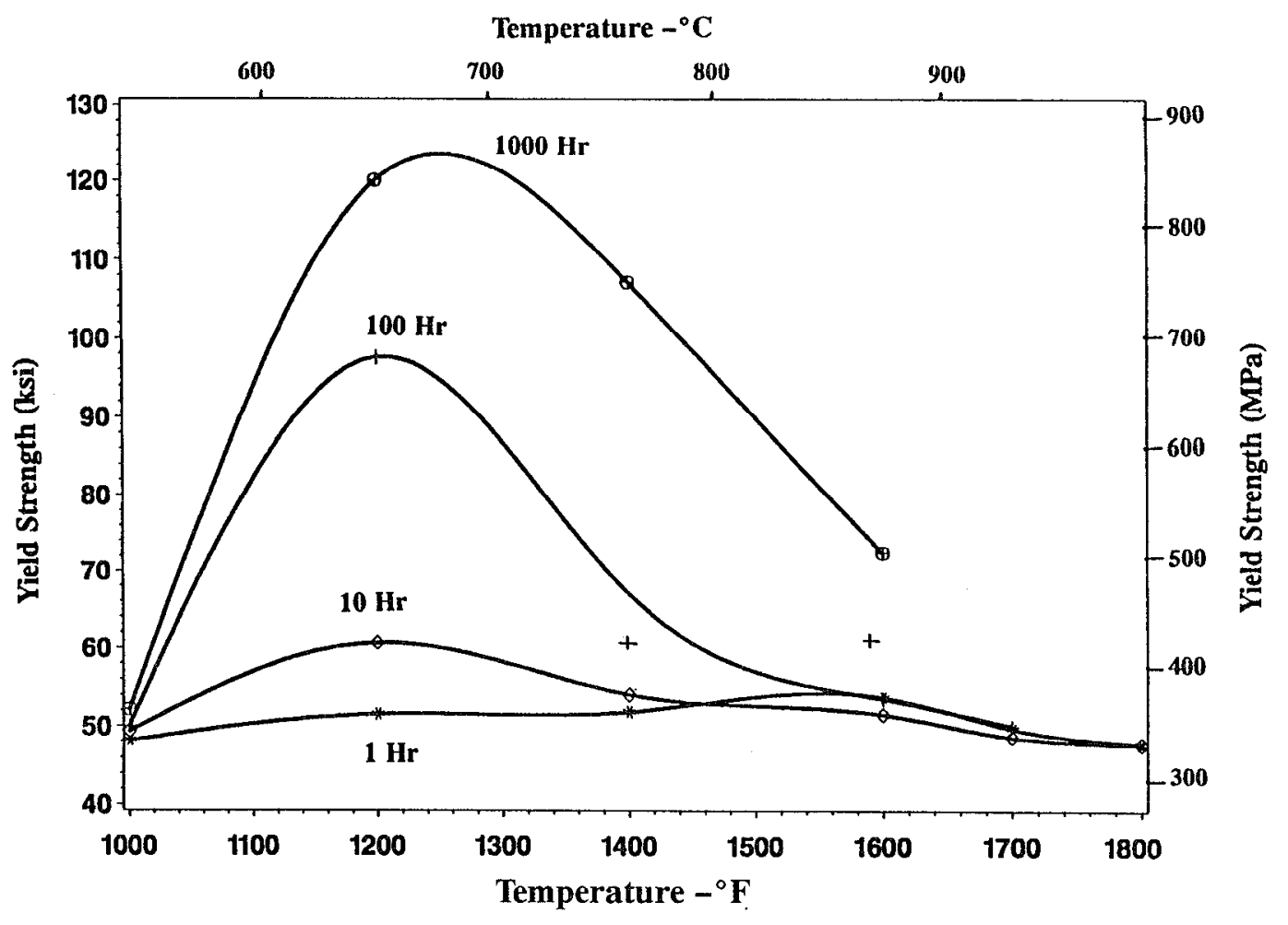

Figure 7. Effect of Exposure on INCONEL alloy 625, Heat Y8869 $(4.11 \% \mathrm{Nb})$ Hot Rolled Bar Heat Treated $1149^{\circ} \mathrm{C}\left(2100^{\circ} \mathrm{F}\right) / 1 \mathrm{Hr}, \mathrm{AC}+$ Exposure

The niobium level, with aluminum and titanium being held to low levels, is very influential in determining the age-hardening response of the alloy. Early in the alloy's history many heats were made with the niobium level in the $4.0-4.2 \%$ area, while most service or application data were from subsequent heats that had lower (3.6-3.8\%) levels of niobium. While higher levels of niobium allow increased levels of strength after an aging cycle, the penalty of decreased room-temperature ductility levels after prolonged service exposure is not worth the small advantage that the capability of intentional aging provides.

This intermediate-temperature, sluggish aging response is undoubtedly the major, and possibly only, drawback of alloy 625. Potential users of the alloy are routinely cautioned about the loss of ductility after exposure to the $593-816^{\circ} \mathrm{C}\left(1100-1500^{\circ} \mathrm{F}\right)$ range. 
Fortunately, the ductility loss is primarily at room temperature - the intermediate temperature ductility is affected very little as illustrated in Table III.

Table III. Effect of 2000 Hour Intermediate Temperature Exposure on alloy 625

\begin{tabular}{|c||c|c|c||c|c|c|}
\hline \multicolumn{1}{|c||}{$\begin{array}{c}\text { Exposure } \\
\text { Temperature, } \\
{ }^{\circ} \mathbf{C}\left({ }^{\circ} \mathbf{F}\right)\end{array}$} & $\begin{array}{c}\text { Properties at Room Temperature } \\
\text { MPa(Ksi) }\end{array}$ & $\begin{array}{c}\text { Y. S. } \\
\mathbf{0 . 2 \%} \text { Offset } \\
\mathbf{M P a}(\mathbf{K s i})\end{array}$ & $\begin{array}{c}\text { Elongation } \\
(\%)\end{array}$ & $\begin{array}{c}\text { Properties at Exposure Temperature } \\
\text { T.S. } \\
\text { MPa(Ksi) }\end{array}$ & $\begin{array}{c}\text { Y.S. } \\
\text { 0.2\% Offset } \\
\text { MPa(Ksi) }\end{array}$ & $\begin{array}{c}\text { Elongation } \\
(\boldsymbol{\%})\end{array}$ \\
\hline \hline No Exposure & $965(140)$ & $479(69.5)$ & 54 & & & \\
\hline $649(1200)$ & $1214(176)$ & $872(126.5)$ & 30 & $1010(146.5)$ & $734(106.5)$ & 54 \\
\hline $760(1400)$ & $1129(163)$ & $738(107)$ & 26 & $585(84.8)$ & $545(79.0)$ & 62 \\
\hline $871(1600)$ & $993(144)$ & $529(76.7)$ & 37 & $284(41.2)$ & $276(40.0)$ & 80 \\
\hline
\end{tabular}

Composition: $62.5 \mathrm{Ni}, 22 \mathrm{Cr}, 8.9 \mathrm{Mo}, 3.68 \mathrm{Nb}, .02 \mathrm{C}$

Material: $2.54 \mathrm{CM}$ (1") Dia., Hot Rolled Bar, Annealed $1038^{\circ} \mathrm{C}\left(1900^{\circ} \mathrm{F}\right)$ for $1 \mathrm{hr}, \mathrm{AC}$

\section{Cracking Problems in Sheet}

In 1964, Stainless Steel Products Co. (SSP) expressed an interest in alloy 625 sheet for possible use as engine bleed ducts and bellows on the McDonnell F-4h fighter with new gas turbine engines. The competing materials were 19-9DL and A-286. The application involved $566-593^{\circ} \mathrm{C}\left(1050-1100^{\circ} \mathrm{F}\right.$ ) and $19.3 \mathrm{MPa}(280 \mathrm{psi})$ pressure. Samples were provided, and alloy 625 was specified for the application. Several years later SSP were encountering forming difficulties with Huntington-produced material and samples were sent to Huntington for evaluation. It was discovered that the nitrogen content of the problem material was variable and quite high, up to $.093 \%$, and that grind marks were contributing to the crack sensitivity of the sheet. Fortunately, a new sheet/strip facility cured the surface problem but considerable effort was spent in solving the high-nitrogen problem. The nitrogen was causing TiN stringers to form, which because of their low ductility were initiation sites for cracks forming during bending. Modifications of the melt practice reduced the nitrogen level of future melts of the alloy and eliminated the cracking problem.

However, because of the relatively high levels of chromium and molybdenum in the alloy, it has a stronger tendency than most nickel alloys to retain nitrogen. The first commercial heat of alloy 625, made in 1962, was melted in an electric arc furnace and direct-rolled from the static-cast ingot. Subsequently, melting was done in the electric arc furnace followed by refining in an argon-oxygen decarburization (AOD) vessel. Further improvements in properties and quality were achieved by remelting in either a vacuum arc remelt (VAR) or electroslag remelt (ESR) furnace. Certain products, such as sheet and plate, are usually vacuum induction melted (VIM) and ESR remelted. Virtually all of the alloy 625 produced currently is remelted in either a VAR or ESR furnace. Vacuum melting is very effective in controlling the nitrogen level in the alloy.

\section{Weldability}

Excellent weldability was one of the prime goals in the alloy development program. While the composition produced a matrix that was essentially a solid-solution type, the presence 
of a relatively high level of niobium and its participation in a long-time aging-type reaction created concern regarding resistance to strain-induced cracking during post-weld exposure to intermediate temperatures. To evaluate this property, Pierce-Miller patch weld tests were conducted with excellent results. Restrained circular welds were exposed to $1000 \mathrm{hrs}$ at $649^{\circ} \mathrm{C}\left(1200^{\circ} \mathrm{F}\right)$, repair welded, and then given additional exposures to $649^{\circ} \mathrm{C}$ $\left(1200^{\circ} \mathrm{F}\right)$ and $704^{\circ} \mathrm{C}\left(1300^{\circ} \mathrm{F}\right)$ with no cracking. Field experience over the last quarter century reinforces the view that alloy 625 is one of the most weldable of the superalloys. Additionally, its ability to tolerate dilution by numerous elements has established it as a premier dissimilar-welding material. For many years, alloy 625 welding products have been used to weld $9 \%$ nickel steel structures that are used in cryogenic applications because of the high strength, ductility and impact strength of the austenitic-type welds and the toleration of dilution from the $9 \%$ nickel steel.

\section{Corrosion Considerations}

Simply from the composition of the alloy it was recognized that it should have outstanding corrosion characteristics in many environments even though our initial laboratory tests were limited to boiling nitric acid. Early evidence of pitting corrosion resistance came from tests at the Francis L. LaQue Corrosion Laboratory at Wrightsville Beach, NC. Most of the corrosion data was developed from comparison test coupons of various corrosion resistant alloys exposed to different environments.

As an alloying element, nickel contributes resistance to many corrosive media, particularly to reducing environments, neutral salt solutions and alkalies and is particularly helpful in preventing stress-corrosion cracking. Chromium, on the other hand, offers little resistance to non-oxidizing media such as hydrochloric acid but has excellent resistance to oxidizing solutions such as nitric acid. Molybdenum, in addition to contributing to mechanical strength as a matrix stiffener, contributes greatly to corrosion resistance in reducing media and in providing pitting resistance. Figure 8 shows how the critical temperature for pitting increases as the chromium and molybdenum content increases. ${ }^{(2)}$ The antipitting power of molybdenum is illustrated by the 2.4 multiplier contained in the composition factor.

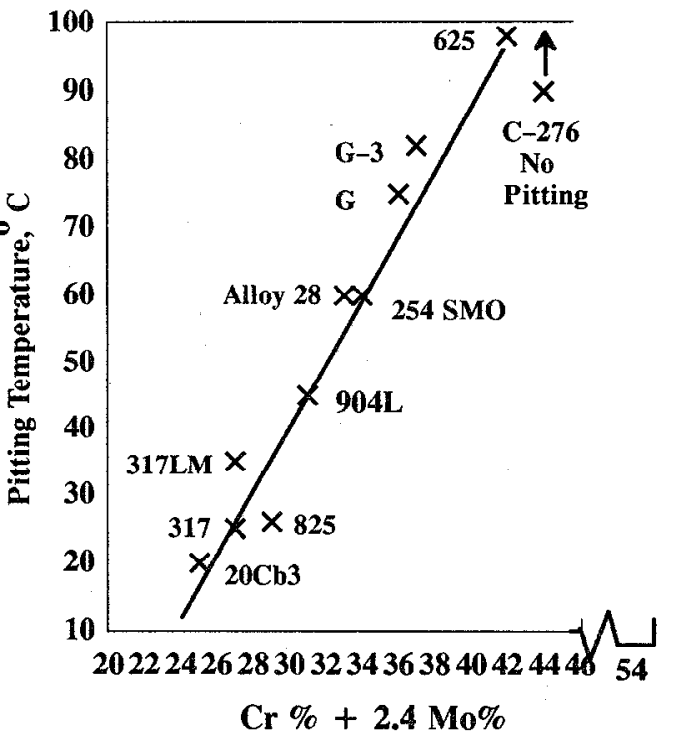

Figure 8. Critical Temperature for Pitting in $4 \% \mathrm{NaCl}+1 \% \mathrm{Fe}_{2}\left(\mathrm{SO}_{4}\right)_{3}+.01 \mathrm{MHC1}$ Versus Composition for $\mathrm{Fe}-\mathrm{Ni}-\mathrm{Cr}-\mathrm{Mo}$ Alloys 
Figure 9 illustrates how increasing levels of nickel lower the corrosion rates in numerous acids, except for nitric acid. ${ }^{(3)}$

Figure 9. Effect of Nickel Content on Corrosion Rate

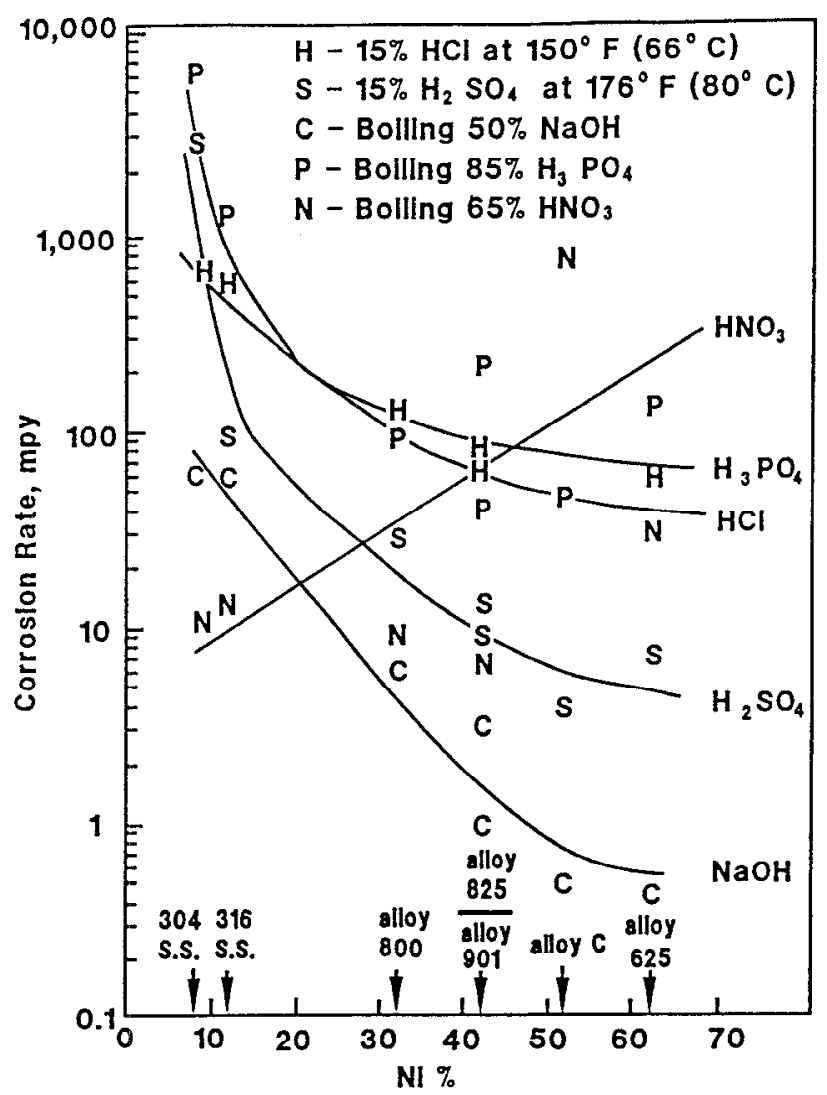

While excellent strength, oxidation resistance and fabricability of alloy 625 contributed to its choice for aerospace applications, its superb corrosion resistance has led to a great deal of success in a wide range of industries. Navy and marine usage is high because of the combination of high strength and resistance to pitting and stress-corrosion cracking. In particular, the alloy is used in critical submarine components where reliability in sea water with crevice conditions is essential. Alloy 625 welding products are often used to overlay steel power-drive shafting because of their good wear characteristics and resistance to sea water pitting and crevice corrosion. In nitric acid production the alloy is routinely used as catalyst grid supports. In the power industry, alloy 625 has been used for many years in scrubber systems and stack liners. Numerous other corrosion-related applications have taken advantage of alloy 625's outstanding and versatile corrosion resistance.

\section{Evolution}

Alloy 625 was invented in the 1950 s and was first sold commercially in 1962. In the nearly 30 years since the first production heat of material was melted, over 100 million pounds of alloy 625 have been produced by nearly two dozen manufacturers. Since that time, there have been numerous variations of the alloy that have been developed, as shown in Figure 10. The most successful, of course, was INCONEL alloy 718, as described earlier. A further modification of alloy 718 was alloy 706 , an age-hardenable alloy being used for 
large turbine wheels because of its high strength, good machinability and capability of being stress-rupture notch ductile in large cross-sections. Several cobalt-containing alloys developed by gas turbine manufacturers to extend the upper service temperature capability of alloy 718 are in use, including Rene $220^{\circledR}$ from GE, and PWA $1472^{\circledR}$ from Pratt \& Whitney.

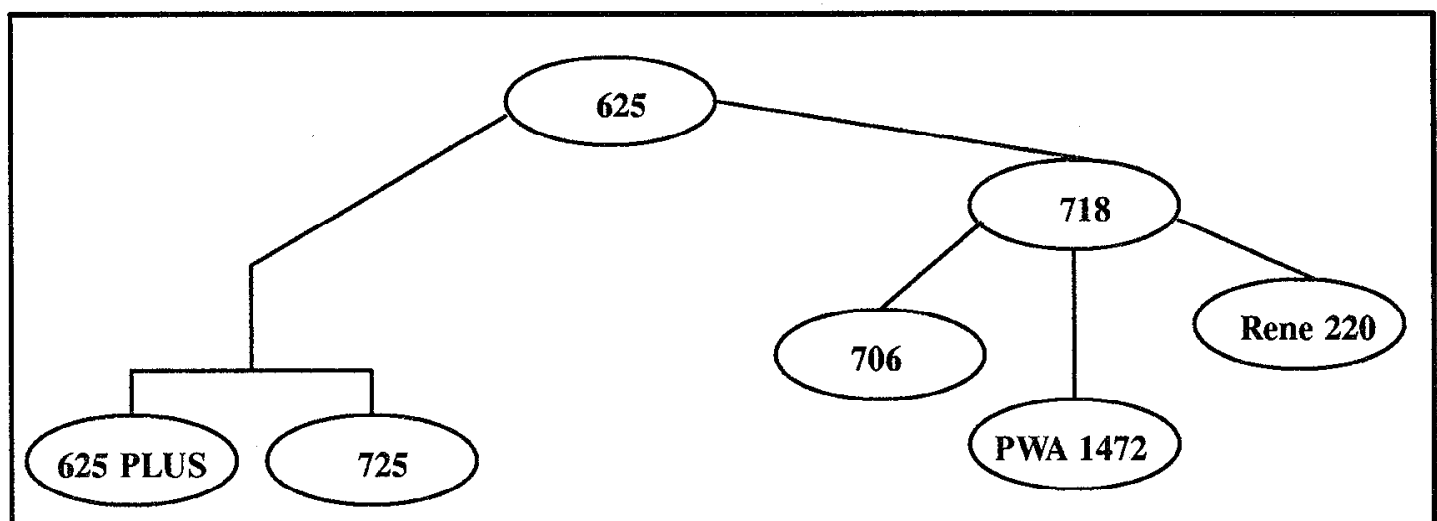

Figure 10. Derivatives of alloy 625

In order to improve the intermediate-temperature low-cycle fatigue (LCF) properties of alloy 625, modifications were made to the carbon, silicon and nitrogen levels. By limiting the carbon level to $0.03 \%$ max, the silicon level to $0.15 \%$ max. and the nitrogen content to $0.02 \%$ max. and by modifying the melting method and annealing practice, a considerable improvement in LCF strength was realized.

All of this was achieved within the limits of the applicable specifications. This refined product was named INCONEL alloy $625 \mathrm{LCF}^{\odot}$. Figure 11 shows the improvement in intermediate temperature LCF strength achieved by alloy 625LCF over alloy $625^{(4)}$. Fatigue-limited sheet applications, such as bellows and expansion joints, are using the enhanced properties of alloy 625LCF to improve the performance and the service life of the part. The fine grain size achieved by the combination of chemistry and processing controls are useful in obtaining superplastic properties, which in turn allows a dramatic im-

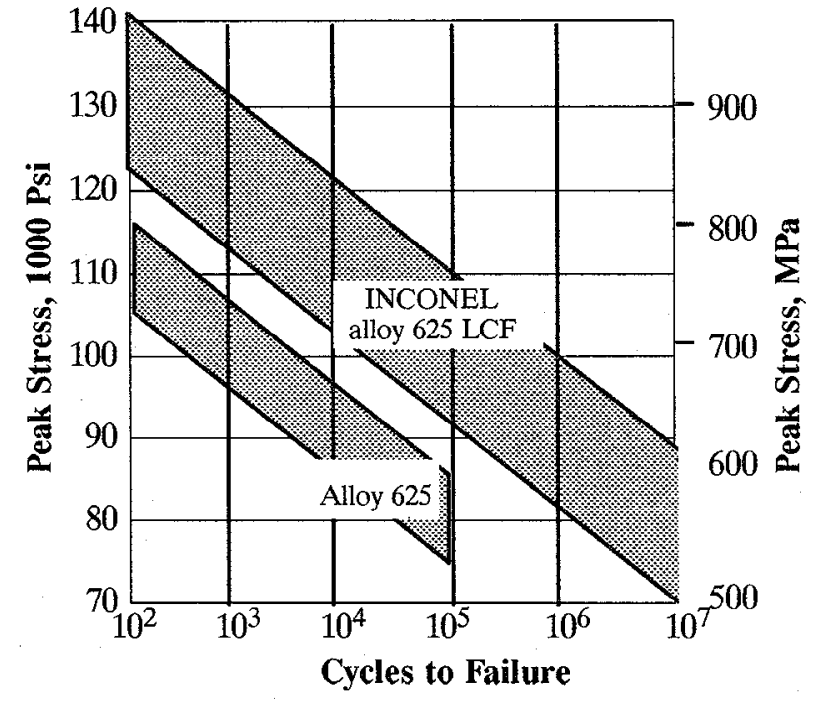

Figure 11. Ranges of low-cycle fatigue strength obtainable with INCONEL alloy 625 LCF and alloy 625 at temperatures of 480 to $650^{\circ} \mathrm{C}\left(900^{\circ} \mathrm{F}\right.$ to $\left.1200^{\circ} \mathrm{F}\right)$ provement in fabricability.

(1)Rene 220 is a trademark of General Electric Co.

${ }^{\circledR}$ PWA 1472 is a trademark of United Technologies Inc. 
Over the years in the petroleum producing industry, the depth of oil and gas wells was increasing and there was more exposure to sour gas environments at higher temperatures. It was recognized that stronger and more corrosion-resistant alloys would be needed to withstand these increasingly aggressive environments. At the time our laboratory in Huntington lacked the necessary kind of high pressure, high temperature, sour gas environment capability. We could run the boiling magnesium chloride stress-cracking test and a room temperature hydrogen embrittlement test. Strip metal test coupons were made into U-bends of compositions ranging from INCONEL alloy 625 through INCONEL alloy 718. These were tested for hydrogen embrittlement. The Inco Research and Development Center in Suffern, NY, was investigating age-hardenable nickel-base alloys for sour gas use by means of appropriate autoclave technology. The amalgamation of these efforts resulted in INCONEL alloy 725 , which possessed an attractive combination of strength and sour gas corrosion resistance. Separately, Cartech was developing a similar alloy, Custom Age 625 PLUS. $^{\odot}$

Alloy 725 is strengthened by precipitation of $y^{\prime \prime}$ during aging. Typical yield strengths of 889 to $1027 \mathrm{MPa}$ (129 to $149 \mathrm{ksi}$ ) are obtained by dual aging after annealing, with excellent ductility values. The alloy is very resistant to sulfide stress cracking in the NACE MR-01-75 environment, stress corrosion cracking in environments containing $\mathrm{NaCl}, \mathrm{H}_{2} \mathrm{~S}$ and $\mathrm{S}$ at high pressures and at temperatures up to $246^{\circ} \mathrm{C}\left(475^{\circ} \mathrm{F}\right)$. It also resists pitting and corrosion by sea water. From a corrosion-resistance standpoint, it is superior to that of age-hardened alloy 718 and is even more crevice-corrosion resistant in sea water in the age-hardened or annealed condition than is alloy 625 in the annealed condition.

The compositions of all of the above-mentioned alloys are listed in Table IV.

Table IV. Typical Compositions of alloy 625 and Its Derivatives

\begin{tabular}{|c|c|c|c|c|c|c|c|c|c|c|}
\hline Alloy & Ni & Cr & Mo & Nb & Al & Ti & C & Si & Fe & Other \\
\hline \hline 625 & 61.0 & 21.5 & 9.0 & 3.6 & .20 & .20 & .06 & .25 & 2.5 & \\
\hline 625 LCF $^{\circledR}$ & 61.0 & 21.5 & 9.0 & 3.6 & .20 & .20 & $.03 M$ & $.15 M$ & 2.5 & N .02M \\
\hline 718 & 52.5 & 19.0 & 3.0 & 5.1 & .50 & .90 & .04 & .18 & 18.5 & B .002 \\
\hline 706 & 41.5 & 16.0 & - & 2.9 & .20 & 1.75 & .03 & .18 & 40.0 & \\
\hline 625 PLUS $^{\circledR}$ & 61.0 & 21.0 & 8.0 & 3.4 & .20 & 1.3 & .01 & .12 & 2.5 & \\
\hline 725 & 57.0 & 21.0 & 8.0 & 3.5 & .25 & 1.5 & .01 & .15 & 9.0 & \\
\hline Rene $^{\circledR} 220$ & 52.5 & 19.0 & 3.3 & 5.1 & .50 & 1.0 & .04 & $<.1$ & Bal & B .005 \\
& & & & & & & & & & Co 12.0 \\
\hline PWA $1472^{\circledR}$ & 58.0 & 12.0 & 3.0 & 6.0 & .60 & 2.0 & .04 & $.15 \mathrm{M}$ & 18.0 & B .002 \\
\hline
\end{tabular}

$M=$ Maximum

(8)INCONEL alloy 625LCF is a trademark of the Inco family of companies ${ }^{\circledR}$ Custom Age 625 PLUS is a trademark of Carpenter Technology 


\section{Summary}

From an initial plan to develop an alloy for service in critical steam applications evolved a material that is used in a wide range of industries. Alloy 625 is used in the aerospace industry because of its high strength, outstanding fatigue and thermal fatigue resistance, oxidation resistance and excellent weldability and brazeability. The outstanding and versatile corrosion resistance of the alloy under a wide range of temperatures and pressures is a primary reason for its wide acceptance in the chemical processing field. Its resistance to stress cracking and excellent pitting resistance in a wide range of water temperatures have enabled it to be used extensively in nuclear applications. Its choice in sea-water applications is a result of a resistance to pitting and crevice corrosion, high corrosion-fatigue strength, high tensile strength and resistance to chloride-ion stress-corrosion cracking. It is often used as a welding material to join dissimilar metals because of its strength and ductility and its ability to tolerate a considerable amount of dilution from other alloys.

As versatile and impressive as alloy 625 is, one of the truly amazing facts about its development history is that it was the seed for the development of alloy 718 , the most successful age-hardenable nickel alloy ever developed. Numerous other spin-off alloy compositions have been, and continue to be, developed. But even after over 30 years of existence, alloy 625 is still very much alive.

\section{REFERENCES}

(1) H. L. Eiselstein, "Metallurgy of a Columbium-Hardened Nickel-Chromium-Iron Alloy", Publication 369, ASTM, 1965

(2) J. Kolts, J.B.C. Wu, P.E. Manning, and A.I. Asphahani, "Highly Alloyed Austenitic Material for Corrosion Resistance", Corrosion Reviews, 6(4)(1986) 279-326

(3) R.C. Scarberry, D.L. Graver, C.D. Stephens, "Alloying for Corrosion Control", Materials Protection, June, 1967, pp.54-57

(4) G.D. Smith, D.H. Yates, "Optimization of the Fatigue Properties of INCONEL alloy 625". Paper presented at International Symposium on Superalloys 718, 625 and Various Derivatives, Pittsburgh, Pa, June 24-26, 1991. 